\title{
New Antiproliferative Polyunsaturated Epoxy-Heneicosane Derivatives Isolated from the Brown Alga Lobophora variegata
}

\author{
Fábio N. Ávila, ${ }^{a}$ Francisco C. L. Pinto, ${ }^{a}$ Pedro B. M. Carneiro, ${ }^{\circ b}$ Kayanny Q. Ferreira, ${ }^{c}$ \\ Diego V. Wilke, ${ }^{c}$ Nádia A. P. Nogueira, ${ }^{d}$ Edilberto R. Silveira ${ }^{\circledR a}$ and \\ Otília Deusdênia L. Pessoa*,a \\ ${ }^{a}$ Departamento de Química Orgânica e Inorgânica, Universidade Federal do Ceará, \\ 60021-970, Fortaleza-CE, Brazil \\ ${ }^{b}$ Campus Ministro Reis Velloso, Universidade Federal do Piauí, 64202-020 Parnaíba-PI, Brazil \\ ${ }^{c}$ Departamento de Fisiologia e Farmacologia, Universidade Federal do Ceará, \\ 60430-275 Fortaleza-CE, Brazil \\ ${ }^{d}$ Departamento de Análises Clínicas e Toxicológicas, Universidade Federal do Ceará, \\ 60430-370, Fortaleza-CE, Brazil
}

\begin{abstract}
Two new polyunsaturated 3,4-epoxy-heneicosane derivatives named as epoxy-lobophorene A and epoxy-lobophorene B were isolated from the brown alga Lobophora variegata, in addition to nine known compounds. The structures of the new compounds were elucidated using a combination of 1D/2D nuclear magnetic resonance (NMR) spectroscopy and high-resolution mass spectrometry (HRMS). The isolated compounds were submitted to antiproliferative assays against the human colon cancer cell line HCT-116, human metastatic prostate cancer PC-3M, murine metastatic melanoma B16-F10 and murine fibroblast cell line L929 and also tested as antibacterial. Both 3,4-epoxy lobophorene A and 3,4-epoxy lobophorene B depicted moderate antiproliferative effect against cell lines. None of them showed antibacterial activity.
\end{abstract} activity

Keywords: Lobophora variegata, brown algae, 3,4-epoxy lobophorenes, antiproliferative

\section{Introduction}

The marine macroalgae or seaweeds are a prolific source of highly bioactive natural compounds of unusual structures. Nowadays, it has been estimated that more than 3,000 secondary metabolites were discovered from these organisms. ${ }^{1}$ In this context, a cytotoxic screening of several extracts from species of marine macroalgae, including red, brown and green algae from the Brazilian coastal line was performed with the purpose of finding bioactive extracts. The hexane extract from the brown alga Lobophora variegata (Dictyotales, Phaeophyceae) was the most promising extract with inhibition concentration mean

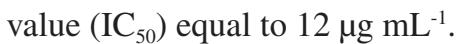

The Lobophora J.Agardh genus is distributed worldwide in tropical and subtropical seas, and represents an important algal component of coral reefs

*e-mail: otilialoiola@gmail.com ecosystems. ${ }^{2}$ The genus comprises approximately 22 species taxonomically accepted, however, more than 80 species have been estimated. ${ }^{3,4}$ Lobophora variegata (J.V.Lamouroux) Womersley ex E.C.Oliveira is the most common species of the genus being the only recognized species in the western Atlantic. ${ }^{5}$ However, Schultz et al., ${ }^{6}$ using a molecular approach for specimens collected in the Caribbean sea, identified four new Lobophora species, increasing the species diversity of the genus. According to a literature review, ${ }^{7-11}$ the secondary metabolites produced by Lobophora species present several biological properties such as antibacterial, antiviral, antioxidant, antitumor, anti-inflammatory, antiprotozoal, pesticidal, and allelopathic.

Although a substantial number of species belonging to Lobophora genus has been already identified, there are only a few reports concerning to their chemical investigations. Gutiérrez-Cepeda et al. ${ }^{11}$ identified 10 new polyketides of L. variegata, while Vieira et al., ${ }^{7}$ performing an ecological 
study, isolated from L. rosacea three new allelopathic polyketide derivatives.

Our group has been focused on a multidisciplinary program devoted to study marine organisms toward bioactive compounds discovery. Herein, it is reported the isolation and characterization of two new polyunsaturated epoxy-heneicosane, in addition to several known compounds (Figure 1), including their antiproliferative and antibacterial evaluation.

\section{Experimental}

\section{General experimental procedures}

Optical rotations were measured on a PerkinElmer 341 digital polarimeter. Infrared (IR) spectra were obtained on a PerkinElmer FT-IR spectrum 1000 spectrometer. High resolution mass spectra (HRMS) were recorded on a Waters Acquity UPLC system coupled with a quadrupole/timeof-flight (TOF) system (UPLC/Qtof MSE spectrometer). Gas chromatography (GC)-MS analysis was carried out on a Shimadzu GCMS-QP2010-Plus spectrometer using a capillary column RTx-5 (30 m × $0.25 \mathrm{~mm}$ i.d., $0.25 \mu \mathrm{m}$ film thickness), He as carrier gas, flow rate of $1.0 \mathrm{~mL} \mathrm{~min}^{-1}$ and split mode (ratio 5:1). Both injector and detector temperatures were 250 and $280{ }^{\circ} \mathrm{C}$, respectively. The column temperature was programmed from 100 to $280^{\circ} \mathrm{C}$ for $20 \mathrm{~min}$ and then from 280 to $310^{\circ} \mathrm{C}$ for $10 \mathrm{~min}$, and held isothermally for $10 \mathrm{~min}$.

Nuclear magnetic resonance (NMR) spectra were acquired either on Bruker DPX-300 or DRX-500 spectrometers. Open column chromatography (CC) was carried out with silica gel (60 or 230 mesh, Merck) or Sephadex LH-20 (Phenomenex), while thin layer chromatography (TLC) was conducted on precoated silica gel aluminum sheets $\left(60 \mathrm{~F}_{254}, 0.20 \mathrm{~mm}\right.$, Merck). Semi-preparative Gemini-Phenomenex C-18 column $(150 \times 10 \mathrm{~mm})$ was used on a UFLC (Shimadzu) system equipped with an SPD-M20A diode array UV-Vis detector. High-pressure liquid chromatography (HPLC) procedures were carried out using photodiode array (PDA) detection 210-400 nm, $200 \mu \mathrm{L}$ injection volume, and flow rate of $2.5 \mathrm{~mL} \mathrm{~min}^{-1}$.<smiles>C=CCCC/C=C\C/C=C\C/C=C\C/C=C\C[C@@H]1O[C@@H]1C=C</smiles><smiles>C=CCCC/C=C\C/C=C\C/C=C\C/C=C\CC1O[C@@H]1CC</smiles><smiles>CC1=C(/C=C/C(C)=C/C=C/C(C)=C/C=C/C=C(C)/C=C/C=C(C)/C=C/C2=C(C)CCCC2(C)C)C(C)(C)CCC1</smiles>

3<smiles>C/C=C(/CC[C@H](C)[C@H]1CC[C@H]2C3CC=C4C[C@@H](O)CC[C@]4(C)[C@H]3CC[C@@]21C)C(C)C</smiles><smiles>C=CCCC/C=C\C/C=C\C/C=C\C/C=C\C[C@H](O)[C@H](O)C=C</smiles>

7<smiles>CC/C=C\C/C=C\C/C=C\CC1OC1[C@@H](O)C/C=C\CCC(=O)O</smiles>

9<smiles>CC(=O)C=CC(C)=CC=C=C1[C@@](C)(O)C[C@@](C)(C=C=C(C)C(C)=O)[C@@H](OC(C)=O)C[C@@]1(C)O</smiles><smiles>C/C(=C\COCC(O)CO)CCCC(C)CCCC(C)CCCC(C)C</smiles>

8<smiles>CC1(C)C[C@@H](O)C[C@]2(C)CC(=O)C=C12</smiles>

10<smiles>CC1(C)C[C@@H](O)C[C@]2(C)CC(=O)C=C12</smiles>

11

Figure 1. Structures of the isolated compounds from Lobophora variegata: 3,4-epoxy-lobophorene A (1); 3,4-epoxy-lobophorene B (2); $\beta$-carotene (3); fucosterol (4); apo-9'-fucoxanthinone (5); apo-13'-fucoxanthinone (6); lobophorenol B (7); phytene glyceryl ether (8); hepoxylin derivative (7,8-HepETE, 9); loliolide (10) and isololoilide (11). 


\section{Biological material}

Specimens of the brown algae Lobophora variegata (J.V.Lamouroux) Womersley $(1.4 \mathrm{~kg})$ were manually collected at the Pedra Rachada Beach, Ceará State, Brazil (323'55.6”S, 3900'47.5'W), during the low tide. A voucher specimen was deposited at Professora Francisca Pinheiro Herbarium (LABOMAR-UFC), under the number HMAR 2997.

\section{Extraction and isolation}

The alga material was dried at room temperature, ground and extracted with $n$-hexane followed by EtOAc and $\mathrm{MeOH}$, to give the respective crude extracts after the solvents evaporation under reduced pressure. The hexane extract (4.20 g) was subjected to CC over silica gel and an increasing mixture of hexane/EtOAc (100:0; 90:10; 80:20; 30:70; 40:60; 50:50; 0:100) as solvents was used to yield the seven correspondent fractions (A-G). Subfraction B (2.16 g) was rechromatographed over silica gel using hexane/EtOAc as the mobile phase to obtain 14 subfractions (BA-BN). Subfraction BG (400.5 mg) was analyzed by HPLC using a Gemini-Phenomenex semipreparative $\mathrm{C} 18$ column $(150 \times 10 \mathrm{~mm})$ and acetonitrile as solvent affording compounds $\mathbf{1}(76.6 \mathrm{mg})$ and $\mathbf{2}(71.1 \mathrm{mg})$. Successive chromatographic procedures of fractions A (206.6 mg) and C (2.28 g), including silica gel CC and Sephadex LH-20, led to the isolation of compounds 3 (6.5 $\mathrm{mg})$ and 4 (615.5 $\mathrm{mg})$.

The EtOAc extract (18.0 g) was fractionated on silica gel, Sephadex LH-20 and HPLC using a semi-preparative C18 column and a solvent system constituted of $\mathrm{H}_{2} \mathrm{O}$ [trifluoroacetic acid (TFA) $0.1 \%$ ]/MeOH in gradient, to yield compounds 5 (5.4 mg), 6 (1.9 mg), 7 (9.7 mg), 8 (26.2 mg), 9 (6.2 mg), 10 (21.0 mg) and 11 (19.0 mg).

\section{3,4-Epoxy-1,6,9,12,15,20-heneicohexaene (3,4-epoxy- lobophorene A) (1)}

Yellowish oil; $[\alpha]_{\mathrm{D}}^{20}-18.06\left(c 0.09, \mathrm{CHCl}_{3}\right)$; UV $(\mathrm{MeOH}) \lambda_{\max } / \mathrm{nm} 202$; IR [attenuated total reflection (ATR) $] \mathrm{v} / \mathrm{cm}^{-1}$ 3011, 2927, 2865, 1639, 986, 912; ${ }^{1} \mathrm{H}$ and ${ }^{13} \mathrm{C} \mathrm{NMR}\left(\mathrm{CDCl}_{3}\right)$ see Table 1; HRESIMS $[\mathrm{M}+\mathrm{H}]^{+}$ $m / z$ 299.2360 (calcd. for $\mathrm{C}_{21} \mathrm{H}_{30} \mathrm{O}, 299.2370$ ); atmospheric pressure chemical ionization (APCI)-MS, $[\mathrm{M}+\mathrm{H}]^{+}$at $m / z$ 299.3.

3,4-Epoxy-6,9,12,15,20-heneicosapentaene (3,4-epoxylobophorene A) (2)

Yellowish oil; $[\alpha]_{\mathrm{D}}^{20}-16.02\left(c 0.09, \mathrm{CHCl}_{3}\right)$; UV $(\mathrm{MeOH}) \lambda_{\max } / \mathrm{nm} 202$; IR (ATR) $v / \mathrm{cm}^{-1} 3012,2970$,
2926, 1640, 990, 910; ${ }^{1} \mathrm{H}$ and ${ }^{13} \mathrm{C} \mathrm{NMR}\left(\mathrm{CDCl}_{3}\right)$ see Table 1; APCI-MS, $[\mathrm{M}+\mathrm{H}]^{+}$at $m / z 301.4\left(\mathrm{C}_{21} \mathrm{H}_{32} \mathrm{O}\right)$.

Table 1. ${ }^{1} \mathrm{H}$ and ${ }^{13} \mathrm{C}$ NMR data comparison of compounds $\mathbf{1}$ and $\mathbf{2}(\delta$ in ppm, $\left.\mathrm{CDCl}_{3}, 500 \mathrm{MHz}\right)$

\begin{tabular}{|c|c|c|c|c|}
\hline & \multicolumn{2}{|c|}{$1\left(\mathrm{CDCl}_{3}, J\right.$ in $\left.\mathrm{Hz}\right)$} & \multicolumn{2}{|c|}{$2\left(\mathrm{CDCl}_{3}, J\right.$ in $\left.\mathrm{Hz}\right)$} \\
\hline & $\delta_{\mathrm{C}}$ & $\delta_{\mathrm{H}}$ & $\delta_{\mathrm{C}}$ & $\delta_{\mathrm{H}}$ \\
\hline 1 & 120.6 & $5.51(\mathrm{~m}), 5.38(\mathrm{~m})$ & 10.8 & $1.06(\mathrm{t}, 7.6)$ \\
\hline 2 & 132.4 & $5.75(\mathrm{~m})$ & 21.2 & $1.62(\mathrm{~m}), 1.55(\mathrm{~m})$ \\
\hline 3 & 57.2 & $3.44(\mathrm{dd}, 6.8,4.2)$ & 58.5 & $2.98(\mathrm{dt}, 6.4,4.3)$ \\
\hline 4 & 58.1 & $3.10(\mathrm{td}, 6.3,4.2)$ & 56.7 & $2.91(\mathrm{dt}, 6.2,4.3)$ \\
\hline \multirow[t]{2}{*}{5} & 26.4 & $2.41(\mathrm{dt}, 14.8,6.6)$ & 26.3 & $2.43(\mathrm{td}, 13.8,6.3)$ \\
\hline & & $2.25(\mathrm{dt}, 14.8,6.5)$ & & $2.24(\mathrm{td}, 13.9,6.5)$ \\
\hline 6 & 124.3 & $5.45(\mathrm{~m})$ & 124.7 & $5.50(\mathrm{~m})$ \\
\hline 7 & 130.9 & $5.48(\mathrm{~m})$ & 130.6 & $5.50(\mathrm{~m})$ \\
\hline 8 & 25.8 & $2.85^{\mathrm{a}}$ & 25.8 & $2.85^{\mathrm{a}}$ \\
\hline 9 & 128.7 & $5.38^{\mathrm{a}}$ & 128.7 & $5.37^{\mathrm{a}}$ \\
\hline 10 & 128.7 & $5.38^{\mathrm{a}}$ & 128.6 & $5.37^{\mathrm{a}}$ \\
\hline 11 & 26.0 & $2.85^{\mathrm{a}}$ & 26.0 & $2.85^{\mathrm{a}}$ \\
\hline 12 & 128.1 & $5.38^{\mathrm{a}}$ & 128.1 & $5.37^{\mathrm{a}}$ \\
\hline 13 & 128.0 & $5.38^{\mathrm{a}}$ & 128.0 & $5.37^{\mathrm{a}}$ \\
\hline 14 & 25.8 & $2.85^{\mathrm{a}}$ & 25.8 & $2.85^{\mathrm{a}}$ \\
\hline 15 & 127.9 & $5.38^{\mathrm{a}}$ & 127.9 & $5.37^{\mathrm{a}}$ \\
\hline 16 & 130.2 & $5.38^{\mathrm{a}}$ & 130.2 & $5.40(\mathrm{~m})$ \\
\hline 17 & 26.8 & $2.09(\mathrm{~m})$ & 26.8 & $2.09(\mathrm{~m})$ \\
\hline 18 & 29.0 & 1.46 (quint, 7.4) & 29.0 & 1.47 (quint, 7.5 ) \\
\hline 19 & 33.5 & $2.09(\mathrm{~m})$ & 33.5 & 2.06 (quint, 6.8) \\
\hline 20 & 138.9 & $5.82(\mathrm{~m})$ & 138.9 & $5.82(\mathrm{~m})$ \\
\hline \multirow[t]{2}{*}{21} & 114.7 & $5.03(\mathrm{~m})$ & 114.7 & $5.02(\mathrm{dd}, 17.2,1.2)$ \\
\hline & & $4.96(\mathrm{~m})$ & & $4.96(\mathrm{dd}, 10.2,0.9)$ \\
\hline
\end{tabular}

${ }^{\mathrm{a}}$ Overlapping of signals.

\section{Antiproliferative activity}

The human colon adenocarcinoma HCT-116, murine metastatic melanoma B16-F10 and murine fibroblast cell lines L929 were purchased from the Banco de Células do Rio de Janeiro (BCRJ, Rio de Janeiro, Brazil), and the human metastatic prostate cancer PC-3M was kindly donated by National Cancer Institute (Bethesda, MD, USA). All cell lines were cultured in Dulbecco's modified Eagle's medium (DMEM, GIBCO®, Darmstadt, Germany) supplemented with fetal bovine serum (10\%) (GIBCO®, Darmstadt, Germany), penicillin (10,000 $\left.\mathrm{U} \mathrm{mL}^{-1}\right)$ and streptomycin $\left(10,000 \mu \mathrm{g} \mathrm{mL}^{-1}\right)\left(\mathrm{GIBCO} 囚\right.$, Darmstadt, Germany) at $37^{\circ} \mathrm{C}$ under $5 \% \mathrm{CO}_{2}$ atmosphere. Cell culture was regularly split to keep them in a logarithm growth phase.

The antiproliferative effect was initially evaluated on HCT-116 cells by the 3-(4,5-dimethyl-2-thiazolyl)2,5-diphenyl-2H-tetrazolium bromide (MTT) assay, as 
described by Mosmann, ${ }^{12}$ after $72 \mathrm{~h}$ incubation with the isolated compounds using concentrations ranging from 0.009 to $250 \mu \mathrm{M}$. Doxorubicin was used as the positive control at concentrations ranging from 0.004 to $12.5 \mu \mathrm{M}$. The experiments were performed two to four times in triplicate. The inhibitory concentration mean $\left(\mathrm{IC}_{50}\right)$ values and their 95\% confidence intervals (CI 95\%) were obtained by non-linear regression of the normalized absorbance data to percentage of growth inhibition using GraphPad Prism software. ${ }^{13}$

The effect on tumor cell density proliferation, based on the measurement of cellular protein content, was further evaluated against HCT-116 (3 experiments), B16-F10 (one experiment), PC-3M (one experiment) and L929 (two experiments) cell lines by the sulforhodamine B (SRB) assay as described by Skehan et al. ${ }^{14}$ Cells were treated with compounds $\mathbf{1}$ and $\mathbf{2}$ with concentrations ranging from 0.01 to $335 \mu \mathrm{M}$ during $72 \mathrm{~h}$. The growth inhibition mean $\left(\mathrm{GI}_{50}\right)$ values, the total growth inhibition (TGI) values, and the lethal concentration mean $\left(\mathrm{LC}_{50}\right)$ values, were analyzed by interpolation of the non-linear regression of normalized absorbance data to the percentage of cell growth using GraphPad Prism. ${ }^{13}$

\section{Antibacterial activity}

The antibacterial activity of compounds $\mathbf{1}$ and 2 was evaluated against two types of bacteria: Staphylococcus aureus (ATCC 6538P, Gram-positive) and Escherichia coli (ATCC 10536, Gram-negative). The isolated colonies of each strain were activated by incubation at $37^{\circ} \mathrm{C}$, overnight, in tryptic soy broth (TSB), and incubated until they reached the exponential growth phase. After this period, the crops had their cellular density adjusted to obtain a turbidity equivalent to the McFarland scale tube 0.5 (approximately $1.5 \times 108$ colony forming units (CFU) $\left.\mathrm{mL}^{-1}\right)$. The different concentrations of the substances (100 to $1.95 \mathrm{mg} \mathrm{mL}^{-1}$ ) were obtained by binary dilutions, from a solution of $1000 \mathrm{mg} \mathrm{mL}^{-1}$, in Tween 80 to $1 \%$ (Sigma-Aldrich, St. Louis, MO, USA), and maintained under refrigeration in a freezer $\left(-20^{\circ} \mathrm{C}\right)$ protected from the light. The minimum inhibitory concentration (MIC) were determined by the broth microdilution method according with the guidelines from the Clinical and Laboratory Standards Institute, M100-S25, ${ }^{15}$ using sterile microplates with 96 flat bottom wells with proper lids. The microplates were incubated for $24 \mathrm{~h}$ at $37{ }^{\circ} \mathrm{C}$. After this, visual inspection of the microbial growth was carried out on an Elisa Bio-Tek to $620 \mathrm{~nm}$. The lowest concentration that completely inhibited microbial growth (MBC) was measured.

\section{Results and Discussion}

Chromatographic fractionation performed over silica gel, Sephadex LH-20, and HPLC of the hexane extract from $L$. variegata, lead to the isolation of the two new compounds.

Compound 1 had its molecular formula $\mathrm{C}_{21} \mathrm{H}_{30} \mathrm{O}$ assigned based on the protonated ion $[\mathrm{M}+\mathrm{H}]^{+}$at $m / z, 299.2360$ (calcd. 299.2370) by HRESIMS with six degrees of unsaturation.

The ${ }^{1} \mathrm{H}$ NMR spectrum showed two sets of chemical shifts at $\delta_{\mathrm{H}} 6.0-5.0$ and $3.5-1.3 \mathrm{ppm}$. The signals at $\delta_{\mathrm{H}}$ 5.82-4.93 were assigned to vinyl protons, whose integrations value $(12 \mathrm{H})$ indicated a long olefinic system. Two terminal vinyl moieties $\left[\delta_{\mathrm{H}} 5.03(\mathrm{dd}, \mathrm{H}-21 \mathrm{a}) / 4.96\right.$ (d, H-21b), $5.82(\mathrm{~m}, \mathrm{H}-20)$ and $5.51(\mathrm{~m}, \mathrm{H}-1 \mathrm{a}) / 5.38$ (m, H-1b), 5.75 (m, H-2)], four non-conjugated cisdisubstituted double bonds $\left(\delta_{\mathrm{H}} 5.48-5.38, \mathrm{~m}\right)$ and six allyl methylenes protons $\left[\delta_{\mathrm{H}} 2.41(\mathrm{dt}, J 14.8,6.6 \mathrm{~Hz}, \mathrm{H}-5 \mathrm{a}) / 2.25\right.$ (dt, $J$ 14.8, $6.5 \mathrm{~Hz}, \mathrm{H}-5 \mathrm{~b}$ ), 2.85 (m, H-8, H-11, H-15), 2.09 (m, H-17, H-19)] were assigned and confirmed through the heteronuclear single quantum correlation (HSQC) spectrum (Table 1). An epoxy group was assigned based on the typical signals at $\delta_{\mathrm{H}} 3.44(\mathrm{dd}, J 6.8,4.2 \mathrm{~Hz}$, $\mathrm{H}-3)$ and $3.10(\mathrm{td}, J 6.3,4.2 \mathrm{~Hz}, \mathrm{H}-4)$, which showed correlations with the carbon signals at $\delta_{\mathrm{C}} 57.2$ and 58.1, in the HSQC spectrum. The ${ }^{13} \mathrm{C}$ NMR spectrum displayed signals to 21 carbon atoms, which were defined into two $\mathrm{sp}^{2}$ and seven $\mathrm{sp}^{3}$ methylenes, two oxymethine and ten vinyl carbons evidencing a long aliphatic chain bearing an epoxy moiety, as observed in the COSY (correlation spectroscopy) spectrum (Figure 2).

The heteronuclear multiple bond correlation (HMBC) spectrum displayed correlations for the protons at $\delta_{\mathrm{H}} 5.51$ (H-1a) /5.38 (H-1b), $5.75(\mathrm{H}-2)$, and $2.41(\mathrm{H}-5 \mathrm{a}) / 2.25(\mathrm{H}-5 \mathrm{~b})$ with the carbon signal at $\delta_{\mathrm{C}} 57.2$ and 58.1, in agreement with the terminal vinyl oxirane moiety. Unfortunately, the overlapping of signals prevented to obtain the $J$ values to define the configuration of double bonds. However, it was possible to suggest the cis configuration for all double bonds based on the allylic methylene chemical shifts $\left(\delta_{\mathrm{C}} 26.8-25.8 \mathrm{ppm}\right)$ since it is well known that allylic methylene carbons of double bonds cis-oriented are more shielded $\left(\delta_{\mathrm{C}}<28 \mathrm{ppm}\right)$ than those trans-oriented $\left(\delta_{\mathrm{C}}>30 \mathrm{ppm}\right){ }^{11,16}$

Comparison of the ${ }^{1} \mathrm{H}$ and ${ }^{13} \mathrm{C}$ NMR data of $\mathbf{1}$ with those reported for the lobophorenol B (7), previously isolated from $L$. rosacea were similar, ${ }^{7}$ only differing by the chemical shifts at $\delta_{\mathrm{C}} 57.2(\mathrm{C}-3)$ and $58.1(\mathrm{C}-4)$, consistent with an epoxy group, instead a trans-3,4-diol. Thus, the structure of $\mathbf{1}$ was established as 3,4-epoxy-lobophorene A. 
Compound 2 had its molecular formula determined as $\mathrm{C}_{21} \mathrm{H}_{32} \mathrm{O}$ based on the protonated $[\mathrm{M}+\mathrm{H}]^{+}$ion at $\mathrm{m} / \mathrm{z}$ 301.4 in the APCI and its ${ }^{13} \mathrm{C}$ NMR APT spectra. The ${ }^{1} \mathrm{H}$ and ${ }^{13} \mathrm{C}$ spectra were like $\mathbf{1}$ (Table 1), except for a shielded set of signals related to an ethyl group at $\delta_{\mathrm{H}} 1.08$ $(\mathrm{t}, J 7.6 \mathrm{~Hz}, 3 \mathrm{H}-1) / \delta_{\mathrm{C}} 10.8,1.62(\mathrm{~m}, 1 \mathrm{H}-2 \mathrm{a}), 1.55(\mathrm{~m}$, $1 \mathrm{H}-2 \mathrm{~b}) / \delta_{\mathrm{C}} 21.2$, consistent with the reduction of the vinyl group in $\mathbf{1}$ attached to oxirane ring. The complete ${ }^{1} \mathrm{H}$ and ${ }^{13} \mathrm{C}$ NMR assignments of $\mathbf{2}$ were made by a combination of $1 \mathrm{D}$ and 2D NMR data and comparison with the assignments described for compound $\mathbf{1}$ and lobophorenes A-C previously reported by Vieira et al. ${ }^{7}$ The ethyl group at $\mathrm{C}-3$ was confirmed by the HMBC correlations of the ethyl protons with the oxirane C-3/4 $\left(\delta_{\mathrm{C}} 58.1 / 56.7\right)$, Figure 2. Thus, the structure of $\mathbf{2}$ was characterized as the 3,4-epoxy-lobophorene B.
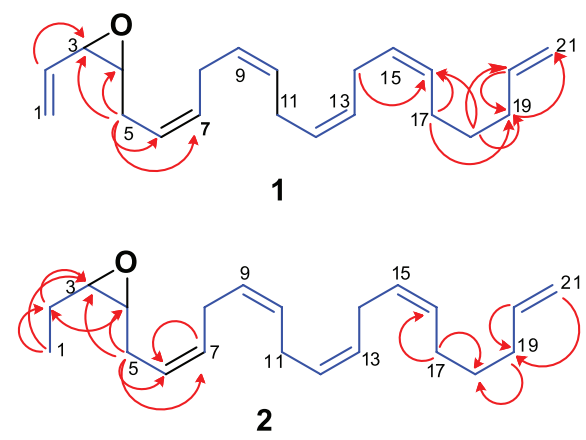

Figure 2. Important COSY (-) and HMBC $(\curvearrowright)$ correlations.
Gutiérrez-Cepeda et al. ${ }^{11}$ have isolated several cyclic lobophorenes bearing an aliphatic side chain to which they proposed a biosynthetic pathway based on the alleged participation of a nonacetate acyl-CoA starter unit involving type III polyketide synthases (PKSs) similar to that observed for the phenolic lipids biosynthesis described by Horinouchi and co-workers. ${ }^{17}$ Since the isolated compounds in this study are structurally similar to the well-known fatty acids from omega-3 series (docosapentaenoic acid (DPA) and docosahexaenoic acid (DHA)), we have rationalized an alternative biosynthetic approach for these compounds based on the classical pathway of unsaturated fatty acids synthesis to give DPA, followed by decarboxylation, epoxigenase and $\Delta$-desaturases steps as suggested in the Scheme $1 . .^{18}$

In addition to the new 3,4-epoxy-lobophorenes $\mathrm{A}$ and $\mathrm{B}$, the known compounds $\beta$-carotene (3), ${ }^{19}$ fucosterol (4), ${ }^{20}$ apo-9'-fucoxanthinone (5), ${ }^{21}$ apo-13'-fucoxanthinone (6), ${ }^{21}$ lobophorenol B (7), ${ }^{18}$ phytane glyceryl ether $(\mathbf{8}),{ }^{22}$ hepoxylin derivative $\left(7,8\right.$-hepETE - 9), ${ }^{23}$ loliolide $(\mathbf{1 0})^{24}$ and isololoilide (11) $)^{24}$ were also isolated.

The MTT assay showed that $\mathbf{1}$, among the tested compounds, was the most active against the human adenocarcinoma cell line HCT-116 showing $\mathrm{IC}_{50}$ equal to 12.2 $\mu$ M. Compounds $\mathbf{2}, \mathbf{6}, \mathbf{7}, \mathbf{8}$, and $\mathbf{9}$ showed weak potency on HCT-116, while $\mathbf{4}$ and $\mathbf{5}$ were not active (see Table 2). The antiproliferative activity of compounds $\mathbf{1}$ and $\mathbf{2}$ was further evaluated by the SRB assay. The $\mathrm{GI}_{50}$ values of $\mathbf{1}$ and $\mathbf{2}$ were

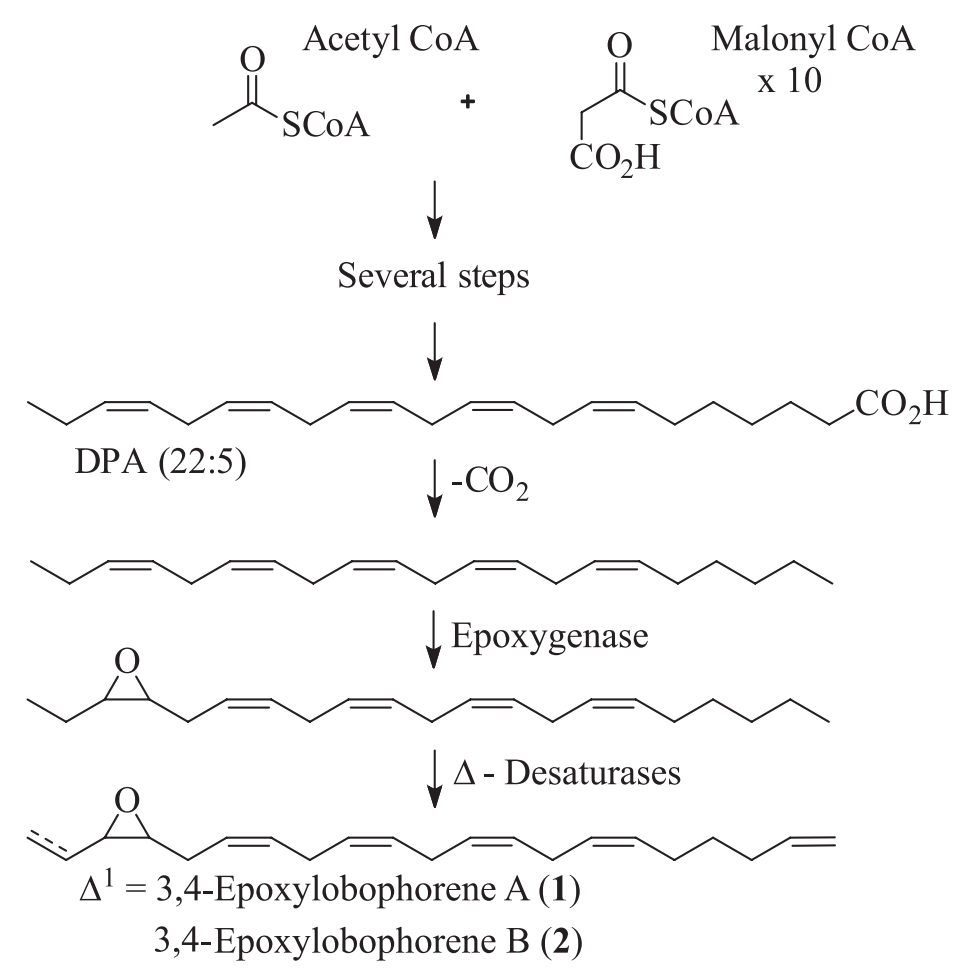

Scheme 1. Suggested approach for the biosynthetic pathway of compounds $\mathbf{1}$ and $\mathbf{2}$. 
the same on HCT-116 cells $(8 \mu \mathrm{M})$. However, 2 was slightly more potent than $\mathbf{1}$ on metastatic cancer cell lines and L929 cells as well (see Table 3). On one hand, the $\mathrm{GI}_{50}$ values of $\mathbf{1}$ and $\mathbf{2}$ on L929 cells were lower than the tumor cell lines tested. On the other hand, $\mathbf{1}$ depicted higher TGI values on L929 comparing with HCT-116 and B16-F10 tumor cells.

Table 2. Antiproliferative activity of compounds 1-11 on a human tumor cell line (HCT-116) by MTT assay after $72 \mathrm{~h}$ incubation

\begin{tabular}{lc}
\hline Compound & $\mathrm{IC}_{50}(\mathrm{CI} 95 \%) / \mu \mathrm{M}$ \\
\hline $\mathbf{1}$ & $12.2(7.1$ to 21.1$)$ \\
$\mathbf{2}$ & $44.3(30.0$ to 65.0$)$ \\
$\mathbf{3}$ & - \\
$\mathbf{4}$ & $>120$ \\
$\mathbf{5}$ & $>180$ \\
$\mathbf{6}$ & $50.0(22.3$ to 112.0$)$ \\
$\mathbf{7}$ & $23.4(10.0$ to 55.0$)$ \\
$\mathbf{8}$ & $41.5(4.5$ to 375.0$)$ \\
$\mathbf{9}$ & $84.5(48.6$ to 147.0$)$ \\
$\mathbf{1 0}$ & $>250$ \\
$\mathbf{1 1}$ & $>250$ \\
Doxorubicin $^{\mathrm{a}}$ & $0.4(0.2$ to 0.6$)$ \\
\hline
\end{tabular}

a Doxorubicin was used as positive control. Data are presented as inhibition concentration mean values $\left(\mathrm{IC}_{50}\right)$ with their confidence intervals of 95\% (CI 95\%) obtained by non-linear regression. Experiments were performed in triplicate. MTT: 3-(4,5-dimethyl-2-thiazolyl)-2,5-diphenyl$2 \mathrm{H}$-tetrazolium bromide.

Table 3. Antiproliferative activity of compounds $\mathbf{1}$ and $\mathbf{2}$ on a panel of cell lines by sulforhodamine B (SRB) assay

\begin{tabular}{lccccc}
\hline \multirow{2}{*}{ Compound } & Effect $^{\mathrm{a}}$ & \multicolumn{3}{c}{ Tumor cell line $^{\mathrm{b}}$} & $\begin{array}{c}\text { Fibroblast } \\
\text { cell line }^{\mathrm{b}}\end{array}$ \\
\cline { 3 - 6 } $\mathbf{1}$ & & HCT-116 & PC-3M & B16-F10 & L929 \\
\hline \multirow{2}{*}{$\mathbf{2}$} & GI $_{50}$ & 8.6 & 16.6 & 38.2 & 5.3 \\
& $\mathrm{TGI}$ & 103.7 & $>168$ & 109.4 & 158.1 \\
& LC $_{50}$ & $>335$ & $>168$ & 313.0 & $>335$ \\
\hline & $\mathrm{GI}_{50}$ & 8.1 & 7.4 & 26.7 & 1.6 \\
& $\mathrm{TGI}$ & 93.1 & $>168$ & 69.8 & 23.6 \\
& $\mathrm{LC}_{50}$ & $>335$ & $>168$ & 182.5 & $>335$ \\
\hline
\end{tabular}

aThe effects are depicted as growth inhibition mean $\left(\mathrm{GI}_{50}\right)$, total growth inhibition (TGI) and lethal concentration mean $\left(\mathrm{LC}_{50}\right)$ values in $\mu \mathrm{M}$

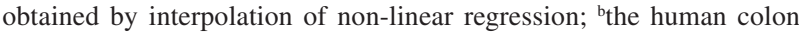
adenocarcinoma (HCT-116), human metastatic prostate cancer (PC-3M), murine metastatic melanoma (B16-F10) and murine fibroblast cell line (L929) were treated with compounds $\mathbf{1}$ and $\mathbf{2}$ with concentrations ranging from 0.01 to $335 \mu \mathrm{M}$ during $72 \mathrm{~h}$ incubation. Experiments were performed in duplicate.

Pheromones of insects have structures like $\mathbf{1}$ and $\mathbf{2}$ and there are no antiproliferative or cytotoxic activities reported to such kind of molecules. ${ }^{25-27}$ Compounds $\mathbf{1}$ and 2 presenting analog structures, displayed activity on tumor and non-tumor cells. The epoxy group of $\mathbf{1}$ is more reactive than the epoxy group of $\mathbf{2}$ and/or the two hydroxyls of $\mathbf{7}$, what could perhaps be explained by the participation of the terminal double-bond neighboring the highly reactive strained epoxy-ring. Despite the slightly higher potency of compound $\mathbf{2}$ on SRB assays (Table 3), the results achieved with 1 were suitable, due to its better inhibition of the tumor cell lines in comparison to the fibroblast cell line.

Compounds 1, 2 and 7 also share remarkable similarities with $n-3$ polyunsaturated fatty acids (PUFAs), eicosapentaenoic acid (EPA) and DHA. ${ }^{28}$ These molecules display antitumor activity through induction of apoptosis in human cancer cells alone or combined with conventional chemotherapeutic agents, for example, $n$-3 PUFAs may increase tumor cells sensitivity to conventional therapies. ${ }^{29-32}$ This is particularly important due to the possibility to improve the efficacy against chemo resistant cancers. ${ }^{33,34}$ Additionally, $n$-3 PUFAs can present cytotoxicity against cancer cells and mild or no effect on normal cells. ${ }^{35}$ This background highlights a great potential of $\mathbf{1}$ to cancer treatment and emphasizes the importance of further preclinical studies with this new molecule.

\section{Conclusions}

The chemical investigation of the Brazilian Lobophora variegata yielded epoxy lobophorene derivatives, which can be the precursors of the previously isolated lobophorenes through simple reactions such as cyclization, oxidation and reduction. The isolation of these compounds can be considered as a landmark for the genus Lobophora. Additionally, 3,4-epoxy-lobophorene-A (1) revealed a moderate antiproliferative profile against tumor cell lines.

\section{Supplementary Information}

Supplementary data are available free of charge at http://jbcs.sbq.org.br as PDF file.

\section{Acknowledgments}

The authors are grateful to Coordenação de Aperfeiçoamento de Pessoal de Nível Superior/Fundação Cearense de Apoio ao Desenvolvimento Científico e Tecnológico (CAPES/FUNCAP, No. 88887.113263/201501) and Instituto Nacional de Ciência e Tecnologia (INCT BioNat, No. 465637/2014-0).

\section{References}

1. Plougerné, E.; da Gama, B. A. P.; Pereira, R. C.; Barreto-Bergter, E.; Front. Cell. Infect. Microbiol. 2014, 4, 174. 
2. Guiry, M. D.; Guiry, G. M.; AlgaeBase; National University of Ireland: Galway, 2017. Available at http://www.algaebase.org, accessed on October 18, 2017.

3. Vieira, C.; D'hondt, S.; De Clerck, O.; Payri, C. E.; J. Phycol. 2014, 50, 1101.

4. El Gamal, A. A.; Saudi Pharm. J. 2010, 18, 1.

5. Wynne, M. J. In Nova Hedwigia, Beihefte; J. Cramer in Borntraeger Science Publishers: Stuttgart, Germany, 2017, vol. 145.

6. Schultz, N. E.; Lane, C. E.; Gall, L. L.; Gey, D.; Bigney, A. R.; Reviers, B.; Rousseau, F.; Schneider, C. W.; Eur. J. Phycol. 2015, 50, 481.

7. Vieira, C.; Thomas, O. P.; Culioli, G.; Genta-Jouve, G.; Houlbreque, F.; Gaubert, J.; De Clerck, O.; Payri, C. E.; Sci. Rep. 2016, 6, 18637.

8. Cantillo-Ciau, Z.; Moo-Puc, R.; Quijano, L.; Freile-Pelegrin, Y.; Mar. Drugs 2010, 8, 1292.

9. Bianco, E. M.; Pires, L.; Santos, G. K.; Dutra, K. A.; Reis, T. N.; Vasconcelos, E. R.; Cocentino, A. L.; Navarro, D. M.; Ind. Crops Prod. 2013, 43, 270.

10. Morrow, K. M.; Bromhall, K.; Motti, C. A.; Munn, C. B.; Bourne, D. G.; Appl. Environ. Microbiol. 2017, 83, e02391-16.

11. Gutiérrez-Cepeda, A.; Fernández, J. J.; Norte, M.; Montalvão, S.; Tammela, P.; Souto, M. L.; J. Nat. Prod. 2015, 78, 1716.

12. Mosmann, T.; J. Immunol. Methods 1983, 65, 55.

13. GraphPad Prism, version 6.1; Intuitive Software for Science, San Diego, CA, 2015.

14. Skehan, P.; Storeng, R.; Scudiero, D.; Monks, A.; McMahon, J.; Vistica, D.; Warren, J. T.; Bokesch, H.; Kenney, S.; Boyd, M. R.; J. Natl. Cancer Inst. 1990, 82, 1107.

15. Clinical and Laboratory Standards Institute (CLSI); CLSI Document M100-S25; Performance Standards for Antimicrobial Susceptibility Testing; Twenty-Fifth Informational Supplement; CLSI: Wayne, PA, USA, 2015.

16. Almeida, J. G. L.; Maia, A. I. V.; Wilke, D. V.; Silveira, E. R.; Braz-Filho, R.; La Clair, J. J.; Costa-Lotufo, L. V.; Pessoa, O. D. L.; Mar. Drugs 2012, 10, 2846.

17. Miyanaga, A.; Funa, N.; Awakawa, T.; Horinouchi, S.; Proc. Natl. Acad. Sci. U. S. A. 2008, 105, 871.

18. Garba, L.; Ali, M. S. M.; Oslan, S. N.; Rahman, R. N. Z. R. B.
A.; J. Appl. Sci. 2017, 17, 295.

19. Tsukida, K.; Saiki, K.; Sugiura, M.; J. Nutr. Sci. Vitaminol. 1981, 27, 551.

20. Ham, Y. M.; Kim, K.-N.; Lee, W. J.; Lee, N. H.; Hyun, C.-G.; Int. J. Pharmacol. 2010, 6, 151.

21. El Hattab, M.; Culioli, G.; Valls, R.; Richou, M.; Piovetti, L.; Biochem. Syst. Ecol. 2008, 36, 447.

22. Kouichi, U.; Naotake, T.; Yuuji. S.; Juji, S.; Jpn. Kokai Tokkyo Koho 10 JPS6028945A 1985. Available at https://patents. google.com/patent/JPS6028945A/en, accessed in September 2018.

23. Fontana, A.; d'Ippolito, G.; Cutignano, A.; Romano, G.; Lamari, N.; Galluci, A. M.; Cimino, G.; Miralto, A.; Lanora, A.; ChemBioChem 2007, 8, 1810.

24. Pan, W.; Liu, K.; Guan, Y.; Tan, G. T.; Nguyen, V. H.; Manh, C.; Soejarto, D. D.; Pezzuto, J. M.; Fong, H. H. S.; Zhang, H.; J. Nat. Prod. 2014, 77, 663.

25. Morin, C.; Rousseau, E.; Fortin, S.; Prostaglandins, Leukotrienes Essent. Fatty Acids 2013, 203, 213.

26. Millar, J. G.; Mitchell, R. F.; Meier, L. R.; Johnson, T. D.; Mongold-Diers, J. A.; Hanks, L. M.; J. Chem. Ecol. 2017, 43, 1056.

27. Frenkel, J.; Vyverman, W.; Pohnert, G.; Plant J. 2014, 79, 632.

28. Abedi, E.; Sahari, M. A.; Food Sci. Nutr. 2014, 2, 5.

29. Yu, N.; Zhu, H.; Yang, Y.; Tao, Y.; Tan, F.; Pei, Q.; Zhou, Y.; Song, X.; Tan, Q.; Pei, H.; Oncotarget 2017, 8, 31.

30. Gao, K.; Liang, Q.; Zhao, Z.; Li, Y.; Wang, S.; World J. Gastroenterol. 2016, 22, 10.

31. Lim, K.; Han, C.; Xu, L.; Isse, K.; Demetris, A. J.; Wu, T.; Cancer Res. 2008, 68, 553.

32. Murray, M.; Hraiki, A.; Bebawy, M.; Pazderka, C.; Rawling, T.; Pharmacol. Ther. 2015, 150, 109.

33. Cho, Y.; Turner, N. D.; Davidson, L. A.; Chapkin, R. S.; Carroll, R. J.; Lupton, J. R.; Exp. Biol. Med. 2014, 239, 302.

34. D'Eliseo, D.; Velotti, F.; J. Clin. Med. 2016, 5, 15.

35. Giros, A.; Grzybowski, M.; Sohn, V. R.; Pons, E.; FernandezMorales, J.; Xicola, R. M.; Sethi, P.; Grzybowski, J.; Goel, A.; Boland, C. R.; Gassull, M. A.; Llor, X.; Cancer Prev. Res. 2009, 2,732 . 